\title{
Abundance of Legume Nodulating Bacteria in Soils of Diverse Land Use Systems in Cameroon
}

\author{
Laurette Ngo Nkot ${ }^{1, *}$, Henri Fankem ${ }^{1}$, Souleymanou Adamou ${ }^{2}$, Albert Ngakou ${ }^{3}$, Dieudonne Nwaga ${ }^{2}$, \\ Francois - Xavier Etoa ${ }^{4}$

\begin{abstract}
${ }^{1}$ Department of Plant Biology, Faculty of Science, University of Douala. Cameroon ${ }^{2}$ Laboratory of Soil Microbiology, Biotechnology Centre, University of Yaounde I., Cameroon ${ }^{3}$ Department of Biological Sciences, Faculty of Science, University of Ngaoundere. Cameroon
\end{abstract} \\ ${ }^{4}$ Department of Biochemistry, Faculty of Science, University of Yaounde I., Cameroon
}

Copyright $(\mathcal{C} 2015$ by authors, all rights reserved. Authors agree that this article remains permanently open access under the terms of the Creative Commons Attribution License 4.0 International License

\begin{abstract}
Improving biological nitrogen fixation through legume nodulating bacteria (LNB) inoculation requires knowledge on the abundance and effectiveness of indigenous population in the ferralsols. The Most Probable Number method (MPN) was used to determine the naturally occurring LNB population in 64 representative soils of four sites in the humid forest zone of Cameroon. Nodulation Macroptilium atropurpureum was examined under tubes experiment in four location sites: Bertoua, Ebolowa, Bokito and Yaounde, and within each of the locations, in four land use systems (LUSs) of different levels of disturbance: mixed farm; fallows; cocoa plantation and forest. The LNB population size varied from 0.78 to $5.25 \mathrm{log}$ units of soil depending on the land use. The most disturbed LUSs (farms and fallows) exhibiting the highest number of LNB on average. Undisturbed ones (cocoa plantation and forest) showed the lowest number of LNB. The percentage of the need for inoculation was more frequent in the forests $(94 \%)$ and plantations $(75 \%)$. It is low in the in the fallows $(25 \%)$ and the farms $(44 \%)$. In total $60 \%$ of the soils analysed need inoculation. These results are important for future investigations on alternative inoculant strains for improving legume production in Cameroon.
\end{abstract}

Keywords Ecology, Macroptilium Atropurpureum, Land Use Systems, MPN, LNB

\section{Introduction}

Ferrallitic red soils of the humid-forest zone of southern Cameroon are known to be generally of low fertility, particularly for nitrogen and phosphorus availability. While the use of nitrogen $(\mathrm{N})$ fertilizers is one of the best mean to farmers to reduce $\mathrm{N}$ deficiencies in Cameroon, their use is limited by their cost and availability. In addition, these fertilizers may induce soil acidification and become less efficient after few cropping seasons [1], leading to a high dependence of soil to $\mathrm{N}$ fertilizers for optimum yield [2]. Fallow practice to restore soil fertility is no longer possible because of land scarcity, and more efficient practices are needed. It is important to develop sustainable systems that integrate an increased demand of food supply by the population while conserving soil fertility in the long term.

Under conditions of low external input, the use biological $\mathrm{N}$ fixation appears to be a cheaper and environmentally friendly source of $\mathrm{N}$ for plants [3]. However, high $\mathrm{N}$ fixation, requires the presence of adequate numbers of highly effective legume nodulating bacteria (LNB) in the soil [4]. For many legumes and soils, either the LNB are absent, occur in low number, or are not highly effective. Consequently, the $\mathrm{N}$ requirements of the crops are not satisfied [2]. Bogino et al. [5] observed a high degree of nodulation and $\mathrm{N}$ fixation in peanut produced by indigenous LNB in some soils from Argentina. Wherever a particular legume is considered as a traditional crop, it is likely that there will be adequate numbers of indigenous LNB for inoculation [6]. Beyond this generalisation, it is difficult to predict situations where inoculation might not be necessary in tropical soils.

Inoculation of legume seed is an efficient and convenient way of introducing viable LNB to soil and subsequently to the legumes rhizosphere [7]. This practice may have significant agronomic benefit in areas where the legume is planted for the first time [8], or in the soil where the number of LNB is too low to allow efficient nodulation of the plant [9]. Inoculation of legumes with LNB is an important process to maximize biological $\mathrm{N}$ fixation capacity in these crops.

However, failure of nodulation or lack of response to inoculation with LNB in the field has been reported, raising doubts about the benefits of inoculation. The presence in the soil of a native rhizobial population that could compete with 
the introduced ones in nodule formation on host plants can limit inoculation benefits [10].

Four land use systems (LUSs) are common in humid forest zone (HFZ) of Cameroon: forest; cocoa or coffee plantation; fallow and mixed farm. Forest conversion to farms or plantations is increasing in response to population growth [11]. Cocoa (Theobroma cacao) plantation, is one of the dominant LUS, has served in the past as an economically-attractive land use but has been rejected by many farmers because of low and unpredictable prices on the world markets. Hence, farmers were forced to abandon cocoa or coffee plantations toward other income-generating opportunities such as food crops. Forest and some old cocoa or coffee plantations are used for annual crops such as groundnut in a mixed farming system.

The number of indigenous LNB could be reduced by LUSs and that can affect legume yield. Mwenda et al. [12] surveyed abundance of LNB in different LUSs in soils from Embu district in Kenya and reported the apparent land use effect on abundance of LNB. According to Nwaga et al. [13], land use changes and cropping practices such as burning may affect soil functioning in the humid forest, along with diversity and occurrence of beneficial micro-organisms. Recently, Izquierdo and Nüsslein [14] have provided strong indication that previous land use history of agricultural activities has a significant long-term and observable effect on the contemporary diazotrophic community composition of secondary growth forest sites. Thies et al. [15] indicated that when limitations other than $\mathrm{N}$ are removed, rhizobial density as estimated by the MPN assay is the primary factor determining the magnitude of response to inoculation.

Inoculation of LNB is not a common practice in the country, but in soils where their number is too low to allow efficient nodulation, an increase in their number may improve grain yield. Therefore, the need for a better knowledge of the ecological parameters such as the indigenous rhizobial populations in the soil is essential to master $\mathrm{N}$ fixation in order to increase legume productivity.

Few data are available on the occurrence of the LNB in the Congo Basin zone in Central Africa. The estimation of the number of LNB in the soil is useful in predicting the likely response of legume to rhizobial inoculation. The objective of this study is to assess under green house conditions the number of LNB in different LUSs representing a gradient of disturbance from low to high.

\section{Materials and Methods}

\subsection{Study Sites, Experimental Design and Treatments}

Experiments were carried out in soil samples collected from four location sites of the HFZ: Bertoua in the East; Ebolowa in the South; Bokito and Yaounde in the Centre regions of Cameroon (Figure 1). In all these regions, slash and burn agriculture is the traditional food production system. The sites were chosen based on the presence of the four LUSs. Generally, after land clearing and burning, the soil is cropped for two to three years, then allowed to fallow for several years. Land abandonment is often attributed to soil fertility depletion. Within each site, soils were collected in four replicates in the four different LUSs: mixed farm (1 to 3 years old), where forest, plantation or fallows are razed and legumes, cassava, and plantains, maize, and others annual crops are grown both for subsistence and for sale; Mixed farm is the rule, and groundnuts (Arachis hypogaea) play an important role in this LUS ; Fallow (3-5 years old) following abandonment and usually dominated by Chromoleana odorata with the crop remnants of cassava and/or plantains; Plantation ( $>20$ years old) being the primary source of income in the past, where farmers grow a single crop: cocoa (Theobroma cacao) or coffee (Coffea arabica, Coffea robusta) and forest ( $>30$ years old) wich is a dominated by a mixed tree species. 

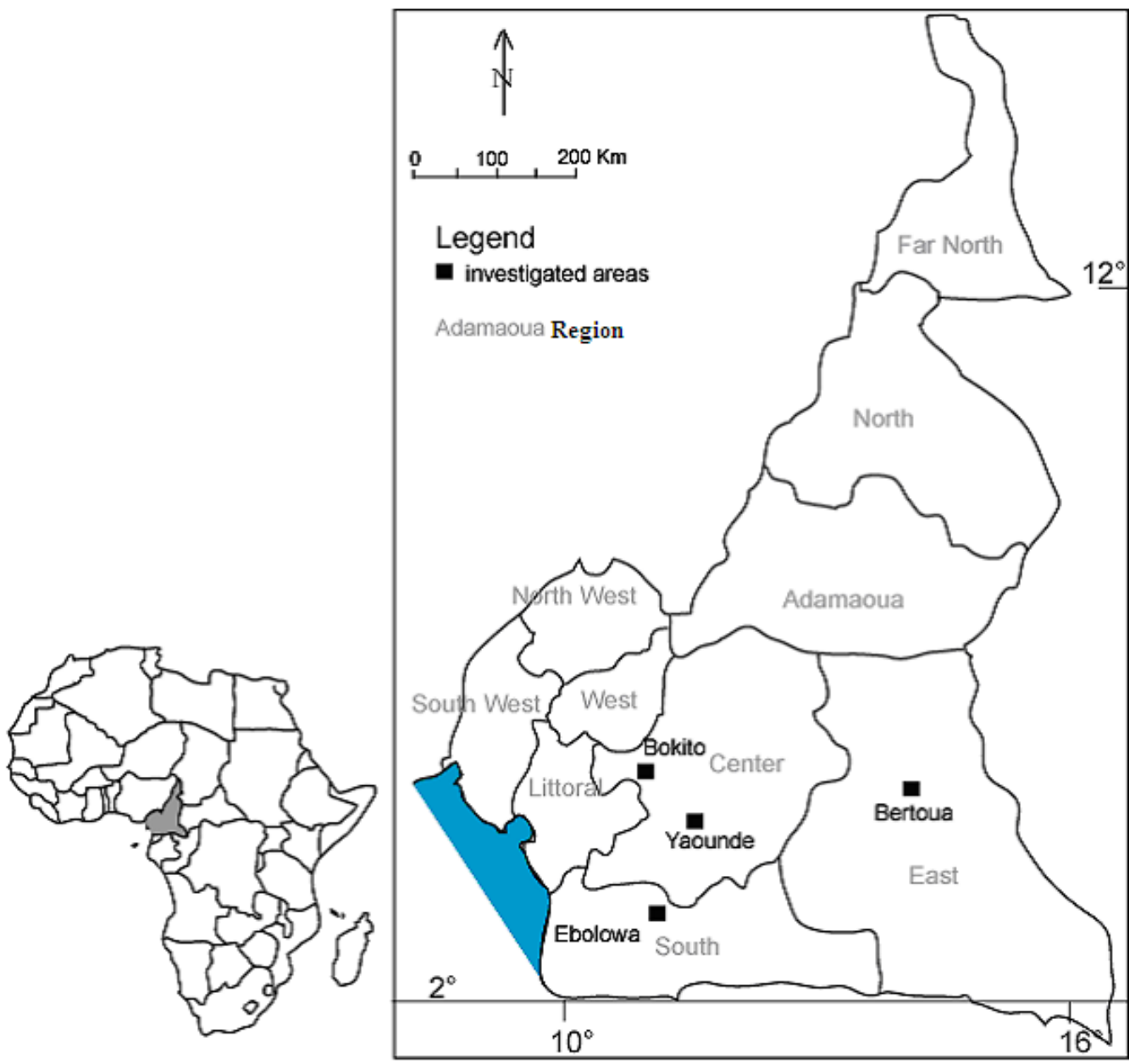

Figure 1. Localisation of Cameroon in Africa and distribution of the investigated sites in HFZ.

\subsection{Soil Sampling and Analysis}

A total of 64 composite soil samples were collected in four location sites according to Swift et al. [16]. Soil sample were taken from sites that had no previous history of LNB inoculation. A composite soil sample was a mixture of ten sub-samples all collected from a LUS of the same location site and kept at $4^{\circ} \mathrm{C}$. The 64 composite samples were taken from the top $0-20 \mathrm{~cm}$ soil depth, from which the un-decomposed plant material were removed by hand. The soil samples from the 10 points were thoroughly mixed, bulked and sub-sampled. One subsample was used to determine the population of soil LNB, while the other one was used for the physical and chemical analysis using Walkley and Black method [17]. The moisture content of each soil sample was determined by drying the soil at $120^{\circ} \mathrm{C}$ for 72 hours. The soil aggregates were gently crushed in a mortar and sieved through a $2 \mathrm{~mm}$ sieve. The bulked samples were analyzed at the Institute of Agricultural Research and Development (IRAD) for soil $\mathrm{pH}$, aluminium, carbon organic by wet oxidation, organic matter and total $\mathrm{N}$ by Kjeldahl digestion.

\subsection{Most Probable Number Counts}

The numbers of indigenous soil LNB able to nodulate legume were estimated by the MPN assay [18] using siratro (Macroptilium atropurpureum) as the trap host. Test tubes of $150 \times 18 \mathrm{~mm}$ are filled approximately $1 / 3$ full with sand and vermiculite for root nodulation. The filled tubes are moistened with distilled water before autoclaving. The racks of prepared tubes are covered loosely with aluminium foil and autoclaved for $20 \mathrm{~mm}$ at $120^{\circ} \mathrm{C}$. Seeds of Macroptilium atropurpureum were scarified and sterilized by immersion in concentrated $\mathrm{H}_{2} \mathrm{SO}_{4}(95 \%)$ for $5 \mathrm{~min}$, thoroughly rinsed with sterile water to eliminate any trace of acid. The seeds were incubated to germinate in sterile Petri dishes containing $0.9 \%(\mathrm{w} / \mathrm{v})$ water agar for $1-2$ days at $28^{\circ} \mathrm{C}$ in the dark. After autoclaving and cooling, tubes are prepared for planting. After germination, single seedlings were transferred aseptically into sterile tubes. After planting, six ten-fold dilutions series, with four replicates per dilution were used to inoculate the tubes ( $1 \mathrm{ml}$ per tube). Uninoculated control plants were used as material control to detect contamination over the growth period. Plants were grown in a growth room at $28 / 20^{\circ} \mathrm{C}$ (day/night) corresponding to 13 -h photoperiod. The plants were irrigated with Jensen nutrient agar free solution [18] when required. Nodulation was assessed after 30 days and MPN of LNB was determined using statistical 
tables [18]. Populations the LNB were grouped into: high: $>$ 1000; moderate: $>100-\leq 1000$; low: $>10-\leq 100$; very low: $\leq 10$ rhizobial cells.g ${ }^{-1}$.

\subsection{Statistical Analysis}

Data were subjected to analysis of variance (ANOVA). Means were separated between treatments with the Least Significant Difference (LSD), using the Statgraphic plus, version 5.0 (SIGMA PLUS) computer package. Comparisons were made among treatments of the same location site and the means were separated using a Tukey's test. A p-value $<0.05$ was used to evaluate significance. A principal component analysis (PCA) was carried out on the basis of the MPN and measured parameters using the same software. The parameters with the treatments were pro-jected on the first two axes of the factorial plane in order to group the sites with their similar characters.

\section{Results}

\subsection{Differences in the Chemical Components of Studied Soils}

The chemical properties of soils under study are shown in table 1 . The soil aluminium content was consistently lower in the fallow $(0.34 \mathrm{meq} / 100 \mathrm{~g})$ than in other LUSs at Bertoua $(\mathrm{p}=0.025)$, whereas at Bokito, it was significantly lower ( $\mathrm{p}$ $=0.013)$ in the forest $(0.28 \mathrm{meq} / 100 \mathrm{~g})$ than the plantation $(0.49 \mathrm{meq} / 100 \mathrm{~g})$. At Ebolowa, the soil aluminium content was significantly lower in the fallow $(0.32 \mathrm{meq} / 100 \mathrm{~g})(\mathrm{p}=$ 0.002 . In contrast, no significant difference was found between the soil aluminium contents of different LUSs in Yaounde. The lower Al value is $0.20 \mathrm{meq} / 100 \mathrm{~g}$ and the higher Alvalue is $0.52 \mathrm{meq} / 100 \mathrm{~g}$.

The soils in this study were classified acidic with $\mathrm{pH}$ ranging from $3.96-6.00$. The land use types had soil $\mathrm{pH}$ ranging from a high of 6.00 in mixed farm at Bertoua to a low of 3.96 in the forest at Ebolowa and did not show significant differences between the LUSs in any of the studied sites. Ebolowa soils were more acid than those of Bertoua, Bokito and Yaounde. Soil organic carbon ranged from $0.88-2.18 \%$, while soil organic matter varied from 1.51 to $3.03 \%$, with a mean value of $2.59 \%$. At Bokito, the soil organic carbon was similar in forest, mixed farm and fallow, but was significantly higher $(p=0.017)$ than in plantation. Similarly, the soil organic matter did not significantly vary between the Ebolowa mixed farm and forest, but was significantly higher $(p=0.05)$ than those of the fallow and plantation. The total mean soil $\mathrm{N}$ value was low and ranged between 0.11 and $0.15 \%$ with little or no variations. Plantation had the most acid LUS soil with an average of 4.85 .

Table 1. Variation of the soil chemical parameters under different land uses of the experimental sites in the HFZ of southern Cameroon

\begin{tabular}{|c|c|c|c|c|c|c|c|}
\hline \multirow{2}{*}{ Sites } & \multirow{2}{*}{ Chemical Parameters } & \multicolumn{4}{|c|}{ Land uses } & \multirow{2}{*}{ p-values } & \multirow{2}{*}{$\operatorname{LSD}(5 \%)$} \\
\hline & & Farms & Fallows & Plantations & Forests & & \\
\hline \multirow{6}{*}{ Bertoua } & $\mathrm{Al}^{3+}(\mathrm{meq} / 100 \mathrm{~g})$ & $0.47 \mathrm{~b}$ & $0.34 \mathrm{a}$ & $0.40 \mathrm{ab}$ & $0.39 \mathrm{ab}$ & 0.025 & $0.127 *$ \\
\hline & $\mathrm{C} / \mathrm{N}$ (ratio) & $8.60 \mathrm{a}$ & $12.04 \mathrm{a}$ & $9.40 \mathrm{a}$ & $8.65 \mathrm{a}$ & 0.561 & ns \\
\hline & $\mathrm{pH}\left(\mathrm{H}_{2} \mathrm{O}\right)$ & $6.00 \mathrm{a}$ & $5.97 \mathrm{a}$ & $5.71 \mathrm{a}$ & $5.54 \mathrm{a}$ & 0.285 & $\mathrm{~ns}$ \\
\hline & $\mathrm{N}(\%)$ & $0.12 \mathrm{a}$ & $0.11 \mathrm{a}$ & $0.11 \mathrm{a}$ & $0.11 \mathrm{a}$ & 0.846 & $\mathrm{~ns}$ \\
\hline & OM (\%) & $1.77 \mathrm{a}$ & $2.05 \mathrm{a}$ & $1.78 \mathrm{a}$ & $1.60 \mathrm{a}$ & 0.549 & $\mathrm{~ns}$ \\
\hline & OC (\%) & $1.03 \mathrm{a}$ & $1.20 \mathrm{a}$ & $1.03 \mathrm{a}$ & $0.93 \mathrm{a}$ & 0.535 & ns \\
\hline \multirow{6}{*}{ Bokito } & $\mathrm{Al}^{3+}(\mathrm{meq} / 100 \mathrm{~g})$ & $0.45 \mathrm{ab}$ & $0.45 \mathrm{ab}$ & $0.49 b$ & $0.28 \mathrm{a}$ & 0.013 & $0.20 * *$ \\
\hline & $\mathrm{C} / \mathrm{N}$ (ratio) & $8.14 \mathrm{a}$ & $8.70 \mathrm{a}$ & $7.99 \mathrm{a}$ & $9.54 \mathrm{a}$ & 0.736 & ns \\
\hline & $\mathrm{pH}\left(\mathrm{H}_{2} \mathrm{O}\right)$ & $5.68 \mathrm{a}$ & $5.71 \mathrm{a}$ & $5.15 \mathrm{a}$ & $5.68 \mathrm{a}$ & 0.830 & ns \\
\hline & $\mathrm{N}(\%)$ & $0.125 \mathrm{a}$ & $0.112 \mathrm{a}$ & $0.115 \mathrm{a}$ & $0.130 \mathrm{a}$ & 0.450 & ns \\
\hline & OM (\%) & $1.72 \mathrm{ab}$ & $1.67 \mathrm{ab}$ & $1.51 \mathrm{a}$ & $2.12 b$ & 0.097 & $0.61 *$ \\
\hline & $\mathrm{OC}(\%)$ & $1.00 \mathrm{ab}$ & $0.97 \mathrm{ab}$ & $0.88 \mathrm{a}$ & $1.22 \mathrm{~b}$ & 0.017 & $0.34 * *$ \\
\hline \multirow{6}{*}{ Ebolowa } & $\mathrm{Al}^{3+}(\mathrm{meq} / 100 \mathrm{~g})$ & $0.52 \mathrm{c}$ & $0.32 \mathrm{a}$ & $0.37 \mathrm{ab}$ & $0.44 \mathrm{bc}$ & 0.002 & $0.122 * *$ \\
\hline & $\mathrm{C} / \mathrm{N}$ (ratio) & $11.62 \mathrm{a}$ & $18.89 \mathrm{~b}$ & $15.37 \mathrm{ab}$ & $17.92 b$ & 0.041 & $6.29^{*}$ \\
\hline & $\mathrm{pH}\left(\mathrm{H}_{2} \mathrm{O}\right)$ & $4.09 \mathrm{a}$ & $4.02 \mathrm{a}$ & $4.14 \mathrm{a}$ & $3.96 \mathrm{a}$ & 0.783 & $\mathrm{~ns}$ \\
\hline & N (\%) & $0.14 \mathrm{c}$ & $0.11 \mathrm{a}$ & $0.13 b c$ & $0.12 \mathrm{ab}$ & 0.005 & $0.01 * *$ \\
\hline & OM (\%) & $2.93 b c$ & $2.15 \mathrm{a}$ & $2.23 \mathrm{ab}$ & $3.03 \mathrm{c}$ & 0.05 & $0.77 *$ \\
\hline & OC (\%) & $1.68 \mathrm{a}$ & $2.15 \mathrm{a}$ & $2.02 \mathrm{a}$ & $2.18 \mathrm{a}$ & 0.222 & ns \\
\hline \multirow{6}{*}{ Yaounde } & $\mathrm{Al}^{3+}(\mathrm{meq} / 100 \mathrm{~g})$ & $0.21 \mathrm{a}$ & $0.20 \mathrm{a}$ & $0.25 \mathrm{a}$ & $0.20 \mathrm{a}$ & 0.488 & $\mathrm{~ns}$ \\
\hline & $\mathrm{C} / \mathrm{N}$ (ratio) & $12.14 \mathrm{a}$ & $8.94 b$ & $8.93 b$ & $8.52 b$ & 0.081 & $3.20 *$ \\
\hline & $\mathrm{pH}\left(\mathrm{H}_{2} \mathrm{O}\right)$ & $4.75 \mathrm{a}$ & $5.15 \mathrm{a}$ & $4.39 \mathrm{a}$ & $5.26 \mathrm{a}$ & 0.325 & ns \\
\hline & $\mathrm{N}(\%)$ & $0.125 \mathrm{a}$ & $0.127 \mathrm{a}$ & $0.145 \mathrm{a}$ & $0.135 \mathrm{a}$ & 0.369 & ns \\
\hline & OM (\%) & $2.55 \mathrm{a}$ & $1.95 \mathrm{a}$ & $2.24 \mathrm{a}$ & $2.04 \mathrm{a}$ & 0.468 & $\mathrm{~ns}$ \\
\hline & OC (\%) & $1.48 \mathrm{a}$ & $1.13 \mathrm{a}$ & 1.30 & $1.17 \mathrm{a}$ & 0.463 & ns \\
\hline
\end{tabular}

Values in a row followed by the same letter within a studied site are not significantly different at $5 \%$ level (ns: non-significant; *: significant; **: highly significant) 


\subsection{Number of LNB in the Soils}

All the soils contained indigenous LNB capable of inducing nodulation of Macroptilium atropurpureum (siratro) which is recommended as a promiscuous host [19]. The total populations of viable LNB nodulating siratro in the soils of HFZ ranged from 0.78 to $5.25 \mathrm{log}$ units of soil. This population differed depending on the LUSs and on the site.

\subsubsection{MPN estimates in the Bertoua soils}

The number of LNB in the soil range from 1.0 to $4.77 \mathrm{log}$ units (Table 2). Soils tested populations of LNB in Bertoua varied from very low (1 soil) to high (1 soil). High density of rhizobial population was detected only in fallows (4.77 log units with an average of 3.19). Moderate number of LNB was detected in all the LUSs: $2.49-3.0$ in the farms, $2.76-$ 3.0 in the fallows, 2.49 in the plantations and 2.23 in the forests. In plantations and forests, lower and very lower numbers of LNB were detected, with an average of 2 and $1.86 \log$ units respectively.

The trend in this site was Fallows $>$ Farms $>$ Plantations $>$ forests.

Table 2. Populations of the LNB in Bertoua soils (1g soil d. m.) and numbers of soils in which LNB were detected

\begin{tabular}{|c|c|c|c|c|}
\hline $\begin{array}{c}\text { Population } \\
\text { of LNB* }\end{array}$ & \multicolumn{4}{|c|}{ Estimated numbers (log) of the LNB and numbers of } \\
& soils (in brackets) \\
\hline High & $(0)$ & $4.77(1)$ & $(0)$ & $(0)$ \\
\hline Moderate & $\begin{array}{c}2.49- \\
3.0(4)\end{array}$ & $\begin{array}{c}2.76- \\
3.0(3)\end{array}$ & $2.49(2)$ & $2.23(2)$ \\
\hline Low & $(0)$ & $(0)$ & $2.0(1)$ & $\begin{array}{c}1.23-1.76 \\
(2)\end{array}$ \\
\hline Very low & $(0)$ & $(0)$ & $1.0(1)$ & $(0)$ \\
\hline
\end{tabular}

* Populations the LNB were grouped by the authors into: high $=>1000$; moderate $=>100-\leq 1000 ;$ low $>10-\leq 100 ;$ very low $=\leq 10$ rhizobial cells in $1 \mathrm{~g}$ soil d.m.

\subsubsection{MPN estimates in the Bokito soils}

Table 3. Populations of the LNB in Bokito soils (1g soil d. m.) and numbers of soils in which LNB were detected

\begin{tabular}{|c|c|c|c|c|}
\hline $\begin{array}{c}\text { Population } \\
\text { of LNB* }\end{array}$ & \multicolumn{5}{|c|}{ Estimated numbers (log) of the LNB and numbers of } \\
soils (in brackets) \\
\hline & Farms & Fallows & Plantations & Forests \\
\hline High & $3,75-$ & $3.49-$ & $3,23-3.49$ & $3.23(1)$ \\
& $4,23(4)$ & $4.49(4)$ & $(2)$ & $2.76(1)$ \\
\hline Moderate & $(0)$ & $(0)$ & $2.23-3.0(2)$ & $2.0(1)$ \\
\hline Low & $(0)$ & $(0)$ & $(0)$ & $0.78(1)$ \\
\hline Very low & $(0)$ & $(0)$ & $(0)$ & 0 \\
\hline
\end{tabular}

* Populations the LNB were grouped by the authors into: high $=>1000$; moderate $=>100-\leq 1000 ; \quad$ low $>10-\leq 100 ; \quad$ very low $=\leq 10$ rhizobial cells in $1 \mathrm{~g}$ soil d.m.

The number LNB ranged from 0.78 to $4.77 \log$ units of soil in Bokito site. In general, a high density of rhizobial population was detected in fallow, with values between 3.49 and 4.77 (Table 3). In farms samples, an average log unit of 3.94 was observed. In plantations and forest, lower number of LNB was detected, with log units averages of 2.99 and 2.19 respectively. High density of rhizobial population was detected only in fallows in all the LUSs (3.23 - $4.49 \log$ units). In the plantations and forests, only moderate number of LNB was detected, $2.23-3.0$ and 2.76 respectively. Low and very low populations of LNB were obtained only in the forests, 2.0 and 0.78 respectively.

The trend in this site was Fallows $>$ Farms $>$ Plantations $>$ Forests.

\subsubsection{MPN estimates in the Ebolowa soils}

In Ebolowa LNB number range from 2.0 to $5.25 \log$ units of soil (Table 4). High population density of LNB was detected in the farms $(4.23-5.25)$ grown with peanut, in the fallows (3.23 - 4.77) and in the plantations (3.23). The average in farms was 4.69 log units, with values from 4.23 to 5.25. The average from fallows samples was $3.87 \mathrm{log}$ units while in the plantations, the average was $2.87 \log$ units. The lowest number of LNB of this site is recorded in forests. The average was 2.49 , with values range from 2.23 à 2.76 . The number of LNB decreased with decreasing of disturbance from farms to forests.

The trend was Farms $>$ Fallows $>$ Plantations $>$ Forests.

Table 4. Populations of the LNB in Ebolowa soils (1g soil d. m.) and numbers of soils in which LNB were detected

\begin{tabular}{|c|c|c|c|c|}
\hline $\begin{array}{c}\text { Population } \\
\text { of LNB* }\end{array}$ & \multicolumn{4}{|c|}{ Estimated numbers (log) of the LNB and numbers of } \\
soils (in brackets) \\
\hline & Farms & Fallows & Plantations & Forests \\
\hline High & $\begin{array}{c}4.23- \\
5.25(4)\end{array}$ & $\begin{array}{c}3.23-4.77 \\
(4)\end{array}$ & $\begin{array}{c}3.23-4.77 \\
(2)\end{array}$ & $(0)$ \\
\hline Moderate & $(0)$ & $(0)$ & $3.0(1)$ & $\begin{array}{c}2.23- \\
2.76(4)\end{array}$ \\
\hline Low & $(0)$ & $(0)$ & $2.0(1)$ & $(0)$ \\
\hline Very low & $(0)$ & $(0)$ & $(0)$ & $(0)$ \\
\hline
\end{tabular}

* Populations the LNB were grouped by the authors into: high $=>1000$ moderate $=>100-\leq 1000 ; \quad$ low $>10-\leq 100 ; \quad$ very low $=\leq 10$ rhizobial cells in $1 \mathrm{~g}$ soil d.m.

\subsubsection{MPN estimates in the Yaounde soils}

In Yaounde LNB number ranged from 1 to $4.23 \log$ units (Table 5). A high population density of LNB was encountered in the fallows (3.69 in average), with values comprising between 2.76 and $4.23 \log$ units. The farms and plantations values extended from 2.76 to 3.23 and 1.76 to $2.76 \log$ units respectively. In the forest in contrast, a low number of LNB was detected with an average of $1.69 \log$ unit.

Table 5. Populations of the LNB in Yaounde soils (1g soil d. m.) and numbers of soils in which LNB were detected

\begin{tabular}{|c|c|c|c|c|}
\hline $\begin{array}{c}\text { Population } \\
\text { of LNB* }\end{array}$ & \multicolumn{4}{|c|}{ Estimated numbers (log) of the LNB and numbers of } \\
soils (in brackets)
\end{tabular}

* Populations the LNB were grouped by the authors into: high $=>1000$; moderate $=>100-\leq 1000 ; \quad$ low $>10-\leq 100 ; \quad$ very low $=\leq 10$ rhizobial cells in $1 \mathrm{~g}$ soil d.m. 
High population density of LNB was detected in the farms (3.23) grown with peanut and in the fallows (3.76-4.23). Moderate number of LNB was detected in the farms $(2.76-$ $3)$, in the plantations $(2.76-3)$ and in the forests $(2.23-$ 2.76). Low number was detected in plantations (1.76) and in the forests $(1.76-2)$. Very low number was obtained only in the forests (1.0).

The trend in this site was Farms $>$ Fallows $>$ Plantations $>$ Forests that had not previously grown with peanut.

These results indicate that LNB can survive in soils for a long time, even in the absence of their host plant. Forests had less LNB than all the other LUSs. LNB, were detected in all the 64 soils examined. In the exception of the farms of Ebolowa that contain $5.25 \mathrm{log}$ units of soil (highest detection level of the test), the MPN of LNB tended to be high in the fallows and low in the plantations and forests. The number of LNB between farms and fallows was not significantly different among all sites. With the exception of Ebolowa site, no significant differences were found between plantations and forests (Figure 2).

In comparing the 64 soils tested (Table 6 ), $40.62 \%$ of the 64 soils sampled contained $>10^{3}$ bacterial cells $\mathrm{g}^{-1}$, while
$59.38 \%$ of soils had $<10^{3}$ bacterial cells $\mathrm{g}^{-1}$. 13 soils populations of these bacteria were low or very low (log $0.78-2,0)$. Moderate numbers of LNB $(\log 2.23-3,0)$ were found in 25 soils, and 26 soils contained high numbers (over 1000 cells g-1.) of these LNB (3.23-5.25). Low or very low were only detected in plantations and forest.

Table 6. Populations of the LNB in the soils ( $1 \mathrm{~g}$ soil d. $\mathrm{m}$.) and numbers of soils in which LNB were detected

\begin{tabular}{|c|c|c|c|c|}
\hline $\begin{array}{c}\text { Population } \\
\text { of LNB* }\end{array}$ & \multicolumn{4}{|c|}{ Estimated numbers (log) of the LNB and numbers of } \\
& Foils (in brackets) & Forests \\
\hline High & $\begin{array}{c}3.23- \\
5.25(9)\end{array}$ & $\begin{array}{c}3.23- \\
4.77(12)\end{array}$ & $\begin{array}{c}3.23-3.49 \\
(4)\end{array}$ & $3.23(1)$ \\
\hline Moderate & $\begin{array}{c}2.49- \\
3.0(7)\end{array}$ & $\begin{array}{c}2.23-3.0 \\
(4)\end{array}$ & $2.23-3.0(7)$ & $\begin{array}{c}2.23-2.76 \\
(7)\end{array}$ \\
\hline Low & $(0)$ & $(0)$ & $1.76-2.0(4)$ & $\begin{array}{c}1.23-2.0 \\
(6)\end{array}$ \\
\hline Very low & $(0)$ & $(0)$ & $1.0(1)$ & $\begin{array}{c}0.78-1.0 \\
(2)\end{array}$ \\
\hline
\end{tabular}

* Populations the LNB were grouped by the authors into: high => 1000; moderate $=>100-\leq 1000 ;$ low $>10-\leq 100 ;$ very low $=\leq 10$ rhizobial cells in $1 \mathrm{~g}$ soil d.m.

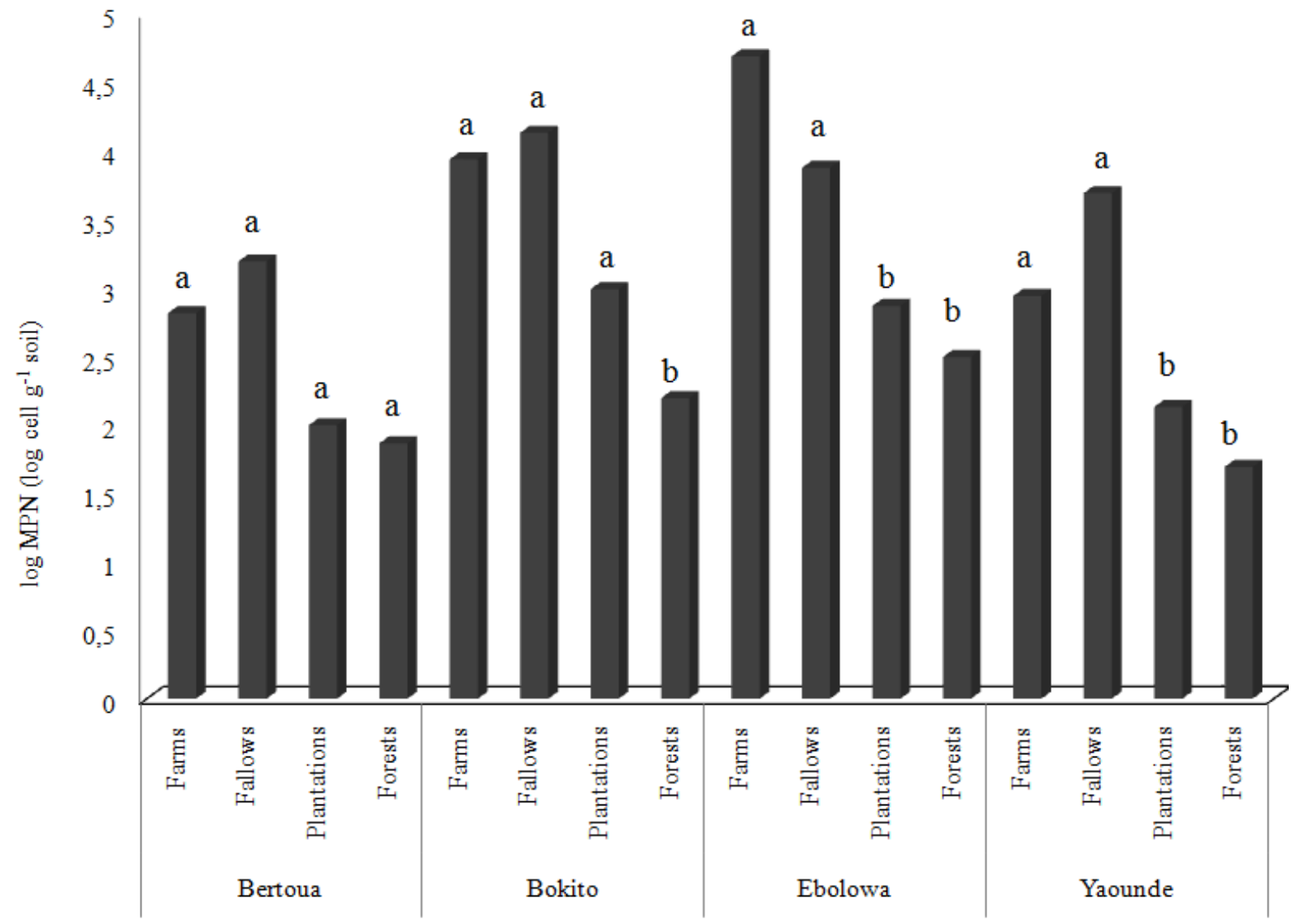

Figure 2. The number of LNB $(\log$ MPN) in function of LUS and site 
Table 7. Relationship between density of rhizobia in soil and response to inoculation

\begin{tabular}{|c|c|c|c|c|c|c|}
\hline & & $\begin{array}{c}\leq 10 \\
\text { Very } \\
\text { low }\end{array}$ & $\begin{array}{c}>10- \\
\leq 100 \\
\text { Low }\end{array}$ & $\begin{array}{c}>100- \\
\leq 1000 \\
\text { Moderate }\end{array}$ & $\begin{array}{c}1000 \\
\text { High }\end{array}$ & \\
\hline LUS & $\mathrm{Nb}$ & & \multicolumn{2}{|c|}{ Nb of samples (\%) } & Observation \\
\hline Farms & 16 & $0(0)$ & $0(0)$ & $7(43.75)$ & $\begin{array}{c}9 \\
(56.25)\end{array}$ & $7(44 \%)$ \\
\hline Fallows & 16 & $0(0)$ & $0(0)$ & $4(25)$ & $12(75)$ & $4(25 \%)$ \\
\hline Plantations & 16 & $\begin{array}{c}1 \\
(6.25)\end{array}$ & $4(25)$ & $7(43.75)$ & $4(25)$ & $12(75 \%)$ \\
\hline Forests & 16 & $\begin{array}{c}2 \\
(12.5)\end{array}$ & $\begin{array}{c}6 \\
(37.5)\end{array}$ & $7(62.52)$ & $\begin{array}{c}1 \\
(6.25)\end{array}$ & $15(94 \%)$ \\
\hline Total & 64 & $\begin{array}{c}3 \\
(4.69)\end{array}$ & $\begin{array}{c}10 \\
(15.63)\end{array}$ & $\begin{array}{c}25 \\
(39.06)\end{array}$ & $\begin{array}{c}26 \\
(40.62)\end{array}$ & $60 \%$ \\
\hline
\end{tabular}

Soils tested populations of LNB of the 64 soils examined varied from very low (3 soils) to high (26 soils). Many soils harbouring high numbers of LNB were found in fallows and farms. In farms, moderate numbers of LNB were obtain in 7 (43.75) and 9 (56.25) contained high numbers of these bacteria. In fallows, moderate numbers of LNB were found in 4 soils $(25 \%)$ and $12(75 \%)$ contained high numbers of these bacteria. In plantations, most of the soils contained moderate number of LNB (7 (43.75\%). High numbers of LNB were found in 4 soils $(25 \%)$, low numbers in 4 soils $(25 \%)$ and very low in 1 soil $(6.25 \%)$. In forests, high and moderate populations of LNB occurred in 8 soils, and low numbers of these bacteria were detected in 6 soils and in 2 soils, these populations were assessed as very low. The percentage of the need for inoculation was more frequent in the forests $(94 \%)$ and plantations $(75 \%)$. It is low in the in the fallows $(25 \%)$ and the farms (44\%) (Table 7). In total $60 \%$ of the soils analysed need inoculation.

In comparing the four sites (Table 8), the presence of soils having less than 100 bacterial cells $\mathrm{g}^{-1}$ was lower in Bokito $(1.56 \%)$ compared to a value of $4.69 \%$ in Bertoua. and $6.26 \%$ in Yaounde. In Ebolowa, no soil had less than 100 bacterial cells /g. Bokito contained higher soils $(68.75 \%)$ with more than $10^{3}$ bacterial cells $\mathrm{g}^{-1}$ than other sites evaluated with an average $\mathrm{pH} 5.56$. The percentage of the need for inoculation was more frequent in the Bertoua (94\%) and Yaounde (75\%). It is low in the in Bokito $(31 \%)$ and Ebolowa (38\%) (Table 8).

Table 8. Density of soil rhizobia in each site and response to inoculation

\begin{tabular}{|c|c|c|c|c|c|c|}
\hline & & $\begin{array}{l}\leq 10 \\
\text { Very } \\
\text { low }\end{array}$ & $\begin{array}{l}>10- \\
\leq 100 \\
\text { Low }\end{array}$ & $\begin{array}{c}>100- \\
\leq 1000 \\
\text { Moderate }\end{array}$ & $\begin{array}{l}>1000 \\
\text { High }\end{array}$ & \\
\hline Sites & $\mathrm{Nb}$ & & \multicolumn{3}{|c|}{$\mathrm{Nb}$ of samples $(\%)$} & Observation \\
\hline Bertoua & 16 & $\begin{array}{c}1 \\
(6.25) \\
\end{array}$ & $\begin{array}{c}3 \\
(18.75) \\
\end{array}$ & $\begin{array}{c}11 \\
(68.75)\end{array}$ & $\begin{array}{c}1 \\
(6.25) \\
\end{array}$ & $15(94 \%)$ \\
\hline Bokito & 16 & $\begin{array}{c}1 \\
(6.25) \\
\end{array}$ & $\begin{array}{c}1 \\
(6.25) \\
\end{array}$ & $3(18.75)$ & $\begin{array}{c}11 \\
(68.75)\end{array}$ & $5(31 \%)$ \\
\hline Ebolowa & 16 & $0(0)$ & $\begin{array}{c}1 \\
(6.25)\end{array}$ & $5(31.25)$ & $\begin{array}{c}10 \\
(62.50)\end{array}$ & $6(38 \%)$ \\
\hline Yaoundé & 16 & $\begin{array}{c}1 \\
(6.25)\end{array}$ & $\begin{array}{c}5 \\
(31.25)\end{array}$ & $6(37.50)$ & $4(25)$ & $12(75 \%)$ \\
\hline Total & 64 & $\begin{array}{c}3 \\
(4.69) \\
\end{array}$ & $\begin{array}{c}10 \\
(15.63) \\
\end{array}$ & $\begin{array}{c}25 \\
(39.06) \\
\end{array}$ & $\begin{array}{c}26 \\
(40.62) \\
\end{array}$ & $\sim 60 \%$ \\
\hline
\end{tabular}

\subsection{Correlations between MPN, Sites, LUSs and Soils Parameters}

The PCA was performed on the correlation matrix of all data studied and treatments (Figure 3). Results showed that the first two axes of the PCA plane explained about $67.06 \%$ of the variability. Silt and total $\mathrm{N}$ were positively correlated between them, and linked to the first axis which explained $49.51 \%$ of the variability. Sand, organic $\mathrm{C}, \mathrm{C} / \mathrm{N}, \mathrm{H}+$ and aluminium were linked to the second axis which explained $67.06 \%$ of the variability. Three main clusters can be identified: the Group 1 included the MPN of two sites (Bertoua and Bokito) and all the LUSs which were linked to the $\mathrm{pH}$ of the soil. The Group 2 included the MPN of the Ebolowa site and was correlated to $\mathrm{Al}+$. The Group 3 included the MPN of the Yaounde site and was linked to total $\mathrm{N}$ and silt. 


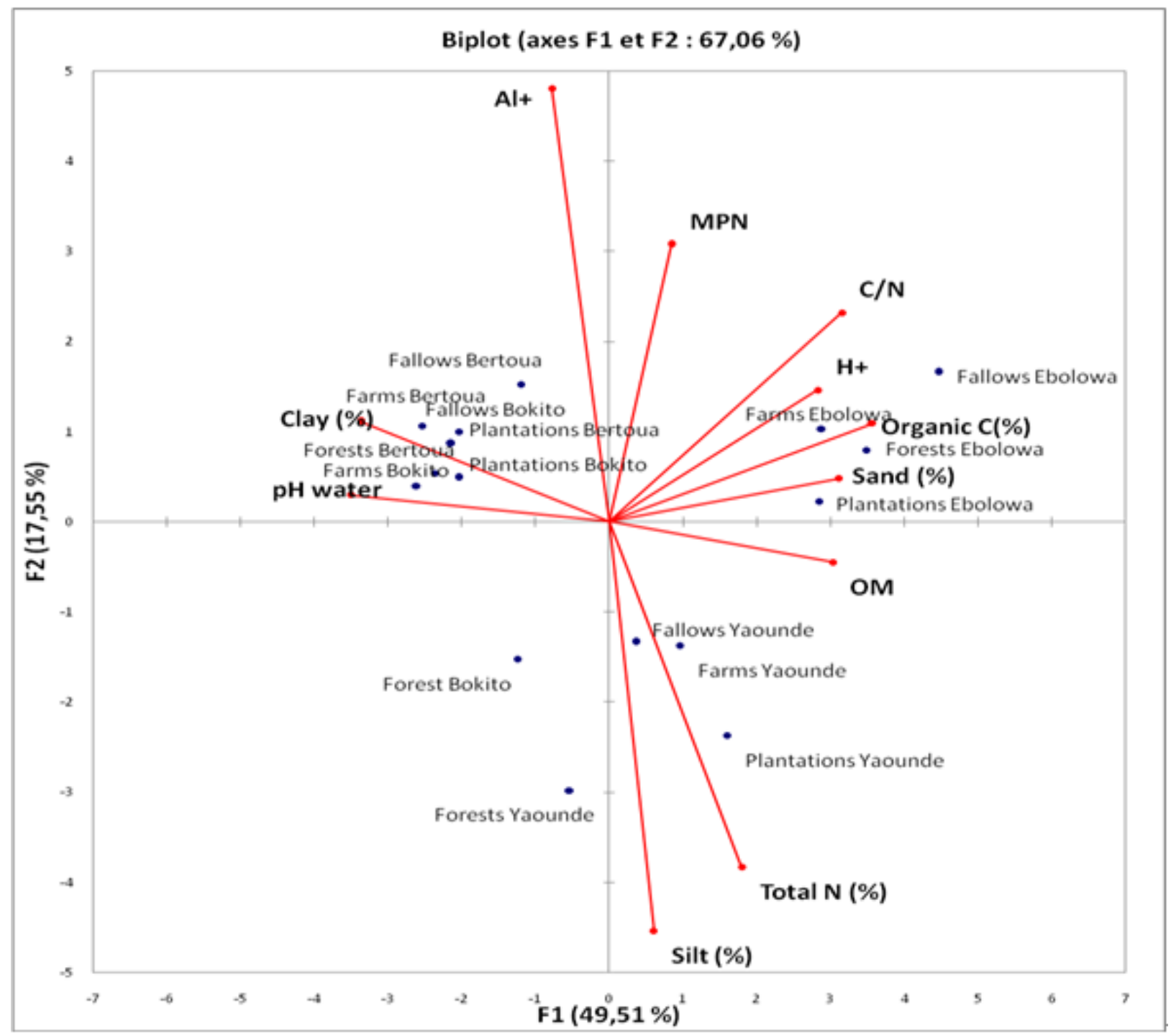

Figure 3. PCA of the soils parameters and MPN of LNB in four LUSs and in four sites

\section{Discussion}

The soils of all the four LUSs were acidic with high aluminium content in most sites. Except in Yaounde, LUSs significantly influence soil aluminium. The low aluminium content in fallow could be due to the residual effect of the wood ash from the slash-and burn practice. Agoumé and Birang [20] also reported that, aluminium saturation was significantly affected by the LUSs with the lowest aluminium saturation obtained in soils of Chromolaena odorata fallows. They noted that soils of fallows presented a higher fertility level as compared to those of the secondary forests and cocoa plantations.

Ebolowa soil was the most acid of all $(\mathrm{pH} 4.07)$, in agreement with other results from which the soils of the south province of Cameroon were acid with $\mathrm{pH}$ ranging from 3.69 to 4.12 [21]. No significant differences were detected in $\mathrm{pH}$ between LUSs. These findings are similar to other results reported by Izquierdo and Nüsslein [14] who showed that no significant differences were detected in $\mathrm{pH}$, organic matter content, or the concentration of total phosphorus or $\mathrm{N}$ species across sampling sites or between land-use histories.

Macroptilium atropurpureum is considered to be a broadly promiscuous host for a wide variety of LNB, especially Bradyrhizobium spp. [22], and it was used to provide an overall assessment of rhizobial abundance. Thrall et al. [23] reported that for many sites the highest rhizobial densities were detected by the promiscuous Macroptilium atropurpureum.

The result obtained in this study highlights the existence of LNB in all the LUSs. Most of the soils examined contained moderate or high populations of LNB. This result is similar to the results of Martyniuk and Oron [24] in Polish soils.

In general, more disturbed LUSs (Fallows and farms) harbour more LNB number than undisturbed one (Forest and plantation). This confirm the results of Ndakidemi et al. [25] who noted that the highest population of native rhizobia was obtained from soils practiced with intensive agriculture involving cultivation of legumes and where compost and 
animal dung manure were used for crop production while the lowest were obtained from both forest (virgin) soils with no agricultural activities and from the soils applied with synthetic N fertilizers. Jesus et al. [26] also found that the size of LNB that can nodulate Macroptilium atropurpureum was very low in the forest whereas this size is high in the farms. The authors conclude that grown species had a stimulating effect on LNB population. LNB in the soil exist as saprophytes. The presence of host plant stimulates the LNB population in the rhizosphere [8]. High LNB density in farms can explain this effect. The stimulating effect of peanut on LNB soil population have already been described by Venkateswarlu et al. [27]. Luangchaisri [28], Anderson and Ingram [17] and others also described the importance of legume in LNB population.

Peanut, which is promiscuous for nodulation was grown in the farms. The higher abundance of LNB in soil under peanut cultivation thus might have resulted for the enrichment by nodulation and release of cells for senescing nodules. This corroborated by the fact that in the plantation and forest in the absence of host legume, the LNB were present in low numbers in the soil. Duodu et al. [29] also reported higher counts of Rhizobium leguminosarum biovar phaseoli only in soil where clover host have been grown. The highest number of LNB in the farms can also be explained by the change of chemical characteristics of these soils. It is well established that legumes can solubilize phosphorus by their roots exudates and enrich the soil with $\mathrm{N}$ and phosphorus [30]. However, this relatively large population of indigenous LNB must be effective in fixing N. In the presence of effective indigenous rhizobial populations, legume could be grown in the farms and fallows without inoculation. Castro et al. [31] indicated a positive response to inoculation of peanut by natural bacterial populations highly adapted, competitive and are capable of replacing an introduced LNB strain.

LNB density is generally higher in the fallows. This confirm the results of Mwenda et al. [12] in six LUSs in Kenyawho also found that the size of LNB that can nodulate Macroptilium atropurpureum was very high in the fallow. The higher abundance of LNB in fallows may due to the best effect of fallow on soil fertility. The soils with high number of LNB were high in fallow (75\%) than in other LUS. There was apparent land use effect on abundance of LNB with fallow system giving high abundance. Ojo and Fagade [32] found that the number of homologous LNB able to nodulate L. leucocephala in Nigeria increased after ten-year fallow.

LNB density is generally lower in cocoa plantations. Ciani and Diriye [33] noted the absence of LNB in soils under banana and papaya plantations compared to soil were leguminous plants such as groundnut and cowpea were cultivated. The decline of LNB in plantation may be the consequence of the application of herbicides widely uses to control weeds in cocoa plantations. Although low in occurrence, LNB were found in the absence of legume. Broomfiel and Ayanaba [34] have shown that the lack of adequate number of Bradyrhizobium japonicum in Nigerian soils was revealed to limit nodulation and $\mathrm{N}$ fixation of soybean, thus decreasing the bean yield.

Mwenda et al. [12] noted the absence of LNB in soils under natural forests. In this study, although LNB were detected in the forests their numbers were low. This result indicates that LNB can survive in soils for a long time, even in the absence of their host plant. Kawaka et al. [35] similarly demonstrated the occurrence of native rhizobia that nodulate common bean in kenyan soils with no history of growing common bean or inoculation. The result of Martyniuk and Oron [24] clearly indicate that the presence and population levels of the alfalfa rhizobia in Polish soils are, strongly dependent on the cultivation of the host crop. Ngo Nkot et al. [36] noted that, soils from plantations and forests were poorly nodulated, whereas those from mixed farming and fallows were highly nodulated. These authors suggest a high variation in groundnut nodulating bacteria density in soils from these LUSs. This low population of LNB in the forest, compared to that found in cultivated farms has been observed previously in Ghana by Fening and Danso [2], with the lowest number in the forest, and the highest numbers occurring in areas where cowpea is commonly cultivated. The low native rhizobial populations in the forest was probably because, for the past 20 years at least, these soils had been under plantations and forest witch exclude the growth of peanut or others cultivated legumes. As shown by Venkateswarlu et al. [27], some non-legumes species have unfavourable effect on the abundance of native rhizobial population. The lowest number of LNB in the forest can also be explained by nutrients deficiencies, especially in HFZ where soils phosphorus is strongly adsorbed by aluminium. Broos et al. [37] found that the numbers of rhizobia also decreased with time in almost all soils and have shown that heavy metal can be most toxic to free living rhizobia in soils in absence of the host plant.

It was found that 50-100 rhizobial cells specific to the host plant per gram of soil is enough to produce a good nodulation [15]. The highest number of soil having less than 1000 LNB $\mathrm{g}^{-1}(59.37 \%$ of soils tested) is an indication that legume plant will probably show a positive response to inoculation in these soils. It is therefore necessary to determine the number and effectiveness of the indigenous LNB on top of assessing their numbers in the soil before a decision is made on whether to inoculate or not. In the plantations and the forests, natural nodulation was not adequate, the numbers of indigenous LNB being below the threshold at which inoculation may be excluded. Consequently, we expected to obtain response to inoculation in the plantations and forests were the number of LNB is low. In contrast, in farms and fallows, the number of LNB may limit response to inoculation.

Thies et al. [4] indicated that density as estimated by the MPN- plant infection assay is one of the primary factors determining the magnitude of response to inoculation. Based on the tendency of MPN estimates of LNB, a recommendation would be to inoculate legumes where MPN populations are less than $1000 \mathrm{LNB}^{-1} \mathrm{~g}^{-1}$ soil [38]. If this recommendation is compared with actual results, inoculation 
would have been recommended for 38 of 64 soil samples. There is a need for inoculation in $60 \%$ of the soils of the HFZ. The percentage of the need for inoculation was more frequent in the forest $(94 \%)$ and plantation $(75 \%)$. It is low in the fallow (25\%) and the farms (44\%).

In cameroonian soils, spontaneous nodulation of peanut (Arachis hypogaea) with promiscuous indigenous LNB has been reported. Results of Mandou et al. [39] have shown that inoculation of groundnuts by LNB provided contrasting responses on different sites in Cameroon, with yield increases of $169 \%$ on a relatively fertile clay soil from Yaounde' and of only 5\% on a mixed farm low-fertility sandy soil from Bokito. The contrasting response to inoculation in the two study sites may be related to density of indigenous LNB populations, since the Bokito soil contained 17000 cells $\mathrm{g}^{-1}$ and the Yaounde' soil only 170. Increased exploitation of beneficial micro-organisms is recommended by FAO for farmers in developing countries. According to Nwaga [40], following inoculation, various grain legumes grown in ferralsols from Cameroon exhibited increases in grain yield ranging from $74 \%$ to $556 \%$, depending on legume species and site. To the agricultural systems of the world, N fixation and biological control provide benefits of over US\$ 90 and 100 billion, respectively [41]. Residual N left in the soil by tropical grain legumes may range from 0 to 205 $\mathrm{kg} \mathrm{N} \mathrm{ha}^{-1}$ [42], which represents a significant added value of the legume crops for the subsequent use of the land. In India, LNB inoculation of groundnut resulted in net income farmer increases of 56\% [43]. In Zimbabwe and Zambia farms, the cost of LNB inoculation is usually less than US\$ $5 \mathrm{ha}^{-1}$ and the estimated return on investment is $1: 100$ and $1: 70$ respectively, in comparison with 1:3 for synthetic $\mathrm{N}$ fertilizer [44]. In Sub-Saharan Africa, the cost of inorganic fertilizers is four to eight times higher than that in Europe, North America or Asia. In Cameroon, where a small production unit of biofertilizers exists, LNB inoculation could be sold at a low cost, and might help in reducing the cost of synthetic $\mathrm{N}$ fertilizer and increasing their efficiency and benefits for farmers.

\section{Conclusions}

Soils of the HFZ of Cameroon contain LNB and an important variation was noticed on the number of LNB according to site and land use. The most disturbed LUSs (farms and fallows) exhibiting the highest number of LNB on average. Undisturbed ones (cocoa plantation and forest) showed the lowest number of LNB. To further increase legume production, inoculation is essential especially where the naturalised rhizobial populations are low. Although some soils contain high number of indigenous LNB, others studies were necessary for characterizing and selecting strains adapted to environmental conditions of the HFZ of Cameroon. These isolates could be investigated to provide additional information on their symbiotic effectiveness with the aim of identifying very effective indigenous strains for local production of a specific peanut inoculant. This work has demonstrated the occurrence of varying population levels of LNB in soils of the HFZ, which were largely affected by the land use systems. The variation in effectiveness can be strongly related to differences in estimated rhizobial abundance among sites and LUSs, suggesting that rhizobial abundance in native soils may therefore be a good indicator of average effectiveness. In Cameroon, local available and inexpensive substrates have shown an important potential as local culture media and carriers in the production of LNB inoculants. The production of LNB inoculants has been done using organic local matter as carriers of inoculants. LNB inoculants will be more accessible for farmers and inoculation would have clear economic benefits in low input agricultural systems like that in Cameroon where chemical fertilizers are not economically affordable.

\section{Acknowledgments}

This study was conducted with funds from the University of Douala. We are also grateful to all the members of the Laboratory of Soil Microbiology, Biotechnology Centre, University of Yaounde I for their participation.

\section{REFERENCES}

[1] Bado BV. 2002. Rôle des légumineuses sur la fertilité des sols ferrugineux tropicaux des zones guinéennes et soudaniennes du Burkina Faso. PhD thesis. Université Laval. 2002. 184p.

[2] Fening JO, Danso SKA. 2002. Variation in symbiotic effectiveness of cowpea bradyrhizobia indigenous to Ghanaian soils. Applied Soil Ecology. 2002; 21: 23-29.

[3] Peoples MB, Herridge DF, Ladha JK. Biological nitrogen fixation: an efficient source of nitrogen for sustainable agricultural production. Plant and Soil. 1995; 174: 3-28.

[4] Thies JE, Singleton PW, Bohlool BB. Influence of the size of indigenous rhizobial populations on establishment and symbiotic performance of introduced rhizobia on mixed farming grown legumes. Applied Environmental Microbiology. 1991a; 57: 19-28.

[5] Bogino P, Banchio E, Rinodi L, Cerioni G, Bonfiglio C, Giordano W. Groundnut (Arachis hypogaea) response to inoculation with Bradyrhizobium sp. in soils of Argentina. Annals of Applied Biology. 2006 ; 148: 207-212.

[6] Thompson JA, Bhomsiri A, Shutsrirung A, Lillankan S. Native root nodule bacteria of traditional soybean growing areas of northern Thailand. Plant and Soil. 1991; 135: 53-65.

[7] Deaker R, Roughley RJ, Kennedy IR. Legume seed inoculation technology-a review. Soil Biology and Biochemistry. 2004; 36: 1275-1288.

[8] Lanier JE, Jordan DL, Spears JF, Wells R, Dewayne Johnson P. Peanut response to inoculation and nitrogen fertilizer. 
Agronomy Journal. 2005; 97:79-84.

[9] Hume DJ, Blair DH. Effect of numbers of Bradyrhizobium japonicum applied in commercial inoculants on soybean seed yield in Ontario. Canadian Journal of Microbiology. 1992; 38: 588-593.

[10] Toro N. Nodulation competitiveness in the Rhizobium-legume symbiosis. World Journal of Microbiology and Biotechnology. 1996; 12: 157-162.

[11] Van Noordwijk M, Williams S, Verbist B. Towards integrated natural resource management in forest margins of the humid tropics: local action and global concern. ASB Lecture Notes Series. 2002.

[12] Mwenda GM, Karanja NK, Boga H, Kahindi JHP, Muigai A, Odee D. Abundance and diversity of legume nodulating rhizobia in soils of embu district, kenya. Tropical and Subtropical Agroecosystems. 2011; 13: 1 - 10 .

[13] Nwaga D, Jansa J, Abossolo Angue M, Frossard E. The Potential of Soil Beneficial Micro-Organisms for Slash-and-Burn Agriculture in the Humid Forest Zone of

[14] Sub-Saharan Africa. In: P. Dion (ed.), Soil Biology and Agriculture in the Tropics, soil biology 21, Springer-Verlag Berlin Heidelberg. 2010; pp. 81-107.

[15] Izquierdo JA, Nüsslein K. Variation in diazotrophic community structure in forest soils reflects land use history. Soil Biology and Biochemistry. 2015; 80:1-8

[16] Thies JE, Singleton PW, Bohlool BB. Modeling symbiotic performance of introduced rhizobia in the field by use of indices of indigenous population size and nitrogen status of the soil. Applied Environmental Microbiology. 1991b; 57(1): 29-37.

[17] Swift MJ, Bignell DE, Huang SP, Cares JE, Moreira F, Pereira EG, Nwaga D, Holt JA, Hauser SStandard methods for assessment of soil biodiversity and land use practice, in The ASA Review Meeting 1999, ASB Project, Bogor, Indonesia, ICRAF. 2001; Vol 1: 40 p.

[18] Walkley A, Black IA. An examination of the degtjareff method for determining soil organic matter and a proposal modification of the chromic acid titration method. Soil Sci. 1934; 37: 29-38.

[19] Vincent JM. A Manual for the Practical Study of Root-Nodule Bacteria. International Biological Programme. Hanbook No. 15. Oxford. UK: Blackwell Scientific Publications. 1970.

[20] Gibson AH, Dreyfus BL, Dommergues YRNitrogen fixation by legumes in the tropics. Martinez Nijhoff / Dr W. Junk Publishers. 1982. The Hague. the Netherlands.

[21] Agoumé V, Birang AM. Impact of land-use systems on some physical and chemical soil properties of an oxisol in the HFZ of southern Cameroon. Tropicultura. 2009; 27 (1): 15-20.

[22] Fankem H, Nwaga D. Deubel A, Dieng L, Merbach W, Etoa FX. Occurrence and functioning of phosphate solubilizing microorganisms from oil palm tree (Elaeis guineensis) rhizosphere in Cameroon. African Journal of Biotechnology. 2006; 5 (24): 2450-2460.

[23] Sprent JI. Nodulation in Legumes. Royal Botanical Gardens, Kew. 2001.
[24] Thrall PH, Slattery JF, Broadhurst LM, Bickford S. Geographic patterns of symbiont abundance and adaptation in native Australian Acacia-rhizobia interactions. Journal of Ecology. 2007; 95: 1110-1122.

[25] Martyniuk S, Oroń J.Populations of rhizobia in some Polish soils not planted with legumes. EKologija. 2008 ; 54 (3) : $165-168$.

[26] Ndakidemi PA, Zephania Mtei K, Gessesse A. Estimates of rhizobia population in soils from northern Tanzania using the most probable number (MPN) counts. African Journal of Agricultural Science and Technology. $2014 ; 2$ : 137-150.

[27] Jesus E, Da C, Moreira FMS, Aparecida Florentino L, Dantas Rodrigues MI, Silva de Oliveira MDiversidade de bactérias que nodulam siratro em três sistemas de uso da terra da Amazônia Ocidental. Pesquisa Agropecuária Brasileria. 2005; $40(8)$ : 769-776.

[28] Venkateswarlu B, Hari K, Katyal JC. Influence of soil and crop factors on the native rhizobial populations in soils under dryland farming. Applied Soil Ecology.1997; 7: 1-10.

[29] Luangchaisri N. Ecological studies and symbiotic performance of soybean rhizobial under different cropping systems in Northeast Thailand. A Ph.D.Thesis. 1995. University of the Philippines.

[30] Duodu S, Bhuvaneswari TV, Gudmundsson J, Svenning MM. Symbiotic and saprophytic survival of three unmarked Rhizobium leguminosarum biovar trifolii strains introduced into the field. Environmental Microbiology. 2005; 7 (7): 1049-1058.

[31] Ae N, Kato Y, Shen RF, Magno B, Horst WJ, Schenk MK, Burkert A, Claassen N, Flessa H, Fromme WB, Goldbach H, Olfs HW, Romheld V. Identification of phosphorus solubilizing active components (PSAC) from root cell wall or groundnut having better growth on an infertile soil among several legume crops, in: Plant nutrition: food security and sustainability of agro ecosystem through basis and applied research. Fourteenth-Int. 2001. Kluwer Academic Publishers, Dordrecht, Netherlands, pp. 523-533.

[32] Castro S, Permigiani M, Vinocur M, Fabra A. Nodulation in peanut (Arachis hypogaea L.) roots in the presence of native and inoculated rhizobia strains. Applied Soil Ecology. 1999; 13: 39-44.

[33] Ojo OA, Fagade OE. Persistence of Rhizobium inoculants originating from Leucaena leucocephala fallowed plots in Southwest Nigeria. African Journal of Biotechnology. 2002; $1(1): 23-27$.

[34] Ciani M, Diriye FU. Presence of rhizobia in soils of Somalia. World Journal of Microbiology and Biotechnology. 1995; 11: 615-617.

[35] Broomfiel ESP, Ayanaba A. The efficiency of soybean inoculation on acid soil in tropical Africa. Plant and Soil. 1980;54: 95-106.

[36] Kawaka F, Dida MM, Opala PA, Ombori O, Maingi J, Osoro $\mathrm{N}$, Muthini M, Amoding A, Mukaminega D, Muoma J. Symbiotic efficiency of ntive rhizobia nodulating common bean (Phaseolus vulgaris L.) in Soils of Western Kenya. International Scholarly Research Notices ; 2014.

[37] Ngo Nkot L, Nwaga D, Ngakou A, Fankem H, Etoa FX. Variation in nodulation and growth of groundnut (Arachis 
hypogaea L.) on oxisols from land use systems of the humid forest zone in southern Cameroon. African Journal of Biotechnology. 2011; 10 (20), 3996-4004.

[38] Broos K, Beyens H, Smolders E. Survival of rhizobia in soil is sensitive to elevated zinc in the absence of the host plant. Soil Biology and Biochemistry. 2005 ; 37: 573-579.

[39] Mandou MMS, Banlock DR, Nwaga D, Foko J. Effet du molybdène et des rhizobia sur la nutrition azotée et le rendement de l'arachide (Arachis hypogaea L.) en champ: étude préliminaire. Biosciences Proceeding. 2002 ; 9: 83-89.

[40] Scott JM, Porter FE. An analysis of the accuracy of a plant infection technique for counting rhizobia. Soil Biology and Biochemistry.1986; $18: 355-362$.

[41] Nwaga D. The Potential of Soil Beneficial Micro-Organisms for Slash-and-Burn Agriculture. In P. Dion (ed.), Soil Biology and Agriculture in the Tropics, Soil Biology 21, DOI 10.1007/978-3-642-05076-3 5, \#Springer-Verlag Berlin Heidelberg 2010
[42] Pimentel D, Wilson C, Mc Cullum C, Huang R, Dwen P, Flack J, Tran Q, Saltman T, Cliff B. Economic and environmental benefits of biodiversity. Bioscience. 1997; 47:747-757.

[43] Giller KE. Nitrogen fixation in tropical cropping systems. CABI, Wallingford, 2001.

[44] Reddy BV, Chinnappa AS, Gopal V, Shankar S. Economic valuation of production impact of legume nodulating bacteria on groundnut production. National workshop on conservation and sustainable management of belowground biodiversity. KFRI, Peechi The Potential of Soil Beneficial Micro-Organisms for Slash-and-Burn Agriculture, 2005.

[45] Anonymous. Economic evaluation of the contribution of below ground biodiversity: Case study of biological nitrogen fixation by rhizobia.

http://www.ciat.cgiar.org/tsbf_institute/pdf/report_2007/outc ome.pdf. Accessed 12 Aug 2009.. 